\title{
PISEMNE PRACE DYPLOMOWE JAKO CZEŚŚĆ REPOZYTORIUM INSTYTUCJONALNEGO AGH W KRAKOWIE. ORGANIZACJA I ZARZĄDZANIE
}

\begin{abstract}
At the end of 2013 the Main Library and the University Computer Centre of the AGH University of Science and Technology (AGH University) joined the conceptual work on the creation of an institutional repository. Entries, requiring universities to check theses with the use of an anti-plagiarism system and to register them in a nationwide repository of diplomas, first noted in the project, and then in the Law on Higher Education act, were the impulse to take up the work. Ultimately, the AGH University's Repository will contain many other types of objects, but considering the deadlines set forth in the act, activities in the area of theses have become a priority in this project. In 2014 detailed rules for placing documents in the repository were developed. In accordance with Rector's authorities' expectations, the development of procedures related to the circulation of current theses and software implementation was completed in June 2015. At the same time, the registration of archive diplomas (which defense was held between October 2009 and May 2015) in a prototype version of the repository has begun. In the paper the conception of the repository and issues related to the organization and management of the project is presented.
\end{abstract}

Słowa kluczowe: repozytor ium instytucjonalne, organizacja, zarządzanie, Biblioteka Główna AGH w Krakowie, Akademia Górniczo-Hutnicza im. Stanisława Staszica w Krakowie

\section{Wstęp}

Idea gromadzenia i organizowania dostępu do elektronicznych źródeł wiedzy, digitalizacji zasobów drukowanych, rękopisów i innych zasobów zaczęła się krystalizować jeszcze w ubiegłym wieku. W latach 90. wraz z ideą społeczeństwa opartego na wiedzy zrodził się ruch open access, którego podstawą było działanie na rzecz budowy otwartego modelu komunikacji naukowej, poprzez tworzenie warunków umożliwiających szybki i trwały dostęp dla każdego do cyfrowych treści naukowych oraz edukacyjnych. W pierwszej kolejności w sieci zaczęły być udostępniane otwarte czasopisma naukowe. Fascynacja możliwościami i wymierne efekty w postaci szerszego dostępu do informacji o prowadzonych badaniach naukowych i ich wynikach czy wzrostu cytowalności, w dalszej kolejności zaowocowały budową bibliotek cyfrowych, a następnie repozytoriów. Już wówczas niektóre biblioteki cyfrowe, tworzone przez 


\section{8}

środowiska akademickie, w pewnym stopniu nosiły znamiona repozytoriów, choć sam termin repozytorium instytucjonalne pojawił się nieco później.

Wedhug Wikipedii ${ }^{1}$ repozytorium instytucjonalne jest to archiwum on-line przeznaczone do gromadzenia, przechowywania i rozpowszechniania cyfrowych wersji wytworów intelektualnej działalności instytucji, w szczególności instytucji badawczej.

W przypadku uczelni akademickich repozytorium zawiera materiały takie jak monografie, artykuły z czasopism uczelnianych, materiały konferencyjne, rozprawy doktorskie. Może również przechowywać inne cyfrowe zasoby wytwarzane w uczelni, jak dokumenty administracyjne, materiały dydaktyczne $\mathrm{i}$ temu podobne.

Jednym z głównych celów prowadzenia repozytorium instytucjonalnego jest zapewnienie otwartego dostępu do wyników badań prowadzonych w danej instytucji poprzez autoarchiwizowanie, w celu globalnego udostępnienia informacji o nich, a także przechowywanie i zachowanie innych cyfrowych zasobów instytucjonalnych, w tym niepublikowanych lub w inny sposób łatwo narażonych na utratę, to jest prace dyplomowe czy też raporty techniczne.

Według Clifforda Lyncha ${ }^{2}$ repozytorium instytucjonalne uczelni to zespół usług, które uniwersytet oferuje członkom swojej społeczności, mających na celu gromadzenie oraz upowszechnianie cyfrowych dokumentów tworzonych przez instytucję i jej członków, a także zarządzanie obiektami $\mathrm{z}$ uwzględnieniem ich długoterminowego zabezpieczenia.

Znaczącym bodźcem dla rozwoju polskich repozytoriów stało się wspólne stanowisko Konferencji Rektorów Akademickich Szkół Polskich i Polskiej Akademii Nauk, przyjęte w 2013 r., w którym stwierdza się, że otwarty dostęp jest istotnym etapem na drodze do wdrożenia otwartych rozwiązań w polskim systemie nauki ${ }^{3}$.

Obecnie w Polsce znaczna liczba uczelni może pochwalić się posiadaniem repozytorium. W bazach tych, często na zasadzie autodeponowania, przede wszystkim rejestrowane są publikacje pracowników i doktorantów. Natomiast prace dyplomowe na ogół gromadzone są w odrębnych systemach uczelnianych (archiwa prac dyplomowych, APD), choć przykładowo na Uniwersytecie Warszawskim w październiku 2014 r. nastąpiło połączenie Repozytorium UW z Archiwum Prac Dyplomowych ${ }^{4}$. Podobne rozwiązanie zastosowane zostanie w Akademii Górniczo-Hutniczej (AGH).

\footnotetext{
${ }^{1}$ Wikipedia, the free encyclopedia, [dostęp: 19.02.2015], http://en.wikipedia.org/wiki/ Institutional_repository.

${ }^{2}$ C.A. Lynch, Institutional Repositories: Essential Infrastructure for Scholarship in the Digital Age, “ARL: A Bimonthly Report” 2003, nr 226, [dostęp: 19.02.2015], http://www. arl.org/resources/pubs/br/br226/br226ir.shtml.

${ }^{3}$ Stanowisko Prezydium KRASP i Prezydium PAN z dnia 5 lipca 2013 r.w sprawie zasad otwartego dostępu do treści publikacji naukowych i edukacyjnych, [dostęp: 17.02.2015], http:// www.krasp.org.pl/pl/uchwaly/uchwaly_krasp.

${ }^{4}$ Repozytorium Uniwersytetu Warszawskiego - promuje i zwiększa cytowania, [dostęp: 24.02.2015], http://www.buw.uw.edu.pl/index.php?option=com_content\&task=view\&id=1561\& Itemid $=241$.
} 


\section{Projekt Repozytorium AGH}

W AGH od 2001 r. budowana była biblioteka cyfrowa, choć pierwszy zdigitalizowany tekst (skrypt uczelniany) Biblioteka Główna udostępniła w Internecie już w 1999 r. ${ }^{5}$ Od 2006 r. w Akademickiej Bibliotece Cyfrowej AGH zaczęto rejestrować rozprawy doktorskie, których obrona odbyła się w AGH, a od 2007 r. - artykuły z uczelnianych czasopism naukowych AGH. W bazie znalazły się także inne typy dokumentów. Wszystkie one zostaną przeniesione do Repozytorium AGH.

Prace nad projektem Repozytorium AGH rozpoczęto pod koniec $2013 \mathrm{r}$. Zasadniczym celem projektu było utworzenie nowego narzędzia wymiany wiedzy i komunikacji naukowej, które umożliwi znacznie szersze upowszechnianie dorobku naukowego pracowników oraz promowanie badań naukowych prowadzonych w AGH. Przyjęto założenie, że zadanie będzie realizowane poprzez gromadzenie wszystkich dokonań Uczelni, jej pracowników, doktorantów i studentów, w szczególności tych, które stanowią podstawę oceny jednostek i osób, a także długoterminowe przechowywanie wszelkich innych cyfrowych zasobów instytucjonalnych.

Docelowo w Repozytorium AGH mają się znaleźć następujące obiekty:

- $\quad$ pisemne prace dyplomowe wraz z dokumentami towarzyszącymi (takie jak: programy komputerowe, mapy, plany oraz recenzje tych prac);

- $\quad$ rozprawy doktorskie bronione w AGH wraz z dokumentami towarzyszącymi;

- $\quad$ artykuły z czasopism wydawanych przez Wydawnictwa AGH lub inne wydawnictwa, których instytucją sprawczą jest AGH, w tym także czasopism organizacji studenckich, działających w Uczelni;

- $\quad$ inne publikacje wydawane przez Wydawnictwa AGH (skrypty, podręczniki akademickie, monografie, rozprawy doktorskie po obronie przeredagowane i wydane w formie monografii i inne);

- publikacje pracowników AGH zamieszczane w źródłach pozauczelnianych;

- materiały źródłowe baz danych tworzonych w BG AGH (BIOGRAM, DHC, ABC-KRAKÓW) lub ich fragmenty;

- dokumenty administracyjne Uczelni (Statut AGH, zarządzenia i pisma okólne rektora, regulaminy, uchwały Senatu, komunikaty kanclerza, kwestora, kadrowe, sprawozdania władz i temu podobne);

- $\quad$ filmy rejestrujące wydarzenia odbywające się na Uczelni, między innymi konferencje czy wystawy;

- $\quad$ fotografie ze zbiorów AGH (baza Foto AGH i inne);

- $\quad$ raporty z badań prowadzonych ze środków publicznych, opisy projektów badawczych;

${ }^{5}$ S. Mitkowski, Elektrotechnika ogólna: ćwiczenia laboratoryjne, Kraków 1999, [dostęp: 19.02.2015], http:// winntbg.bg.agh.edu.pl/skrypty/0002/. 
- zasoby edukacyjne tworzone na platformie Open AGH, takie jak kursy, skrypty, testy, ćwiczenia, prezentacje i symulacje tworzone przez pracowników, studentów i doktorantów AGH;

- $\quad$ zbiory Muzeum AGH;

- $\quad$ zasoby Archiwum Uczelni;

- $\quad$ inne materiały niepublikowane (na przykład wewnętrzne opracowania dla potrzeb władz Uczelni), wskazane przez Rektora AGH;

- $\quad$ obiekty badawcze.

Po przeprowadzeniu analizy dostępnych programów do obsługi Repozytorium AGH wybrane zostało oprogramowanie DSpace. Przez kolejne miesiące trwały prace nad dostosowaniem DSpace-a do potrzeb Repozytorium oraz opracowaniem jego struktury i funkcjonalności. Przygotowano też instrukcję tworzenia metadanych w formacie Dublin Core dla różnych typów obiektów oraz wytyczne odnośnie do formatów prezentacyjnych i macierzystych dla poszczególnych rodzajów obiektów cyfrowych. Opracowano szczegółowe zasady umieszczania dokumentów w Repozytorium AGH.

W pierwotnej wersji projektu przyjęto założenie, że w pierwszej kolejności do Repozytorium AGH przejęte zostaną publikacje z Akademickiej Biblioteki Cyfrowej - AGH, a w dalszej kolejności stopniowo wprowadzane będą pozostałe obiekty, wymagające dodatkowych prac przygotowawczych (digitalizacja, Optical Character Recognition - OCR, wybór i porządkowanie, pozyskiwanie danych ze źródeł zewnętrznych).

\section{Pisemne prace dyplomowe w Repozytorium AGH}

W lipcu 2014 r. pojawiła się znowelizowana ustawa Prawo o szkolnictwie wyższym ${ }^{6}$, w której znalazły się, zapowiadane już wcześniej w projekcie ustawy, zapisy obligujące uczelnie do sprawdzania z wykorzystaniem programów antyplagiatowych, pisemnych prac dyplomowych przed egzaminem i przesyłanie ich, niezwłocznie po zdaniu egzaminu przez studenta, do Zintegrowanego Systemu Informacji o Nauce i Szkolnictwie Wyższym POL-on, do Ogólnopolskiego Repozytorium (pisemnych) Prac Dyplomowych (ORPD) ${ }^{7}$.

W ORPD mają się znaleźć pisemne prace dyplomowe, których obrona, zakończona pozytywnym wynikiem, odbyła się po 30 września 2009 r. Termin, jaki ustawodawca wyznaczył uczelniom do wykonania powyższego zadania, to 31 grudnia $2016 \mathrm{r}$. Z uwagi na narzucone ustawą terminy niezbędne okazało się dokonanie weryfikacji wskazanego wyżej harmonogramu prac. Zdecydowano, że w kolejnych miesiącach zespół projektowy, pracujący nad Repozytorium AGH, skupi się wyłącznie na pracach dyplomowych, pozostawiając na później opracowanie procedur, związanych z innymi typami obiektów.

${ }^{6}$ Ustawa z dnia 11 lipca 2014 r. o zmianie ustawy Prawo o szkolnictwie wyższym oraz niektórych innych ustaw, „Dziennik Ustaw” 2014.1198, art. 167 a, 167 b.

${ }^{7}$ Ibidem, art. 167 b, ust. 1. 
Część uczelni wdrożyła już kilka lat temu elektroniczne systemy obsługi prac dyplomowych. Zasadniczo są one elementem systemów obsługujących dziekanaty. Pozostałe uczelnie czeka opracowanie lub dopracowanie procedur, wybór i implementacja oprogramowania, dostosowanie się do wymogów stawianych przez POL-on.

W AGH przyjęto rozwiązanie, które zakłada, że na bazie oprogramowania DSpace funkcjonować będą dwa, powiązane ze sobą, systemy:

- System Obsługi Prac Dyplomowych (SOPD);

- Repozytorium AGH.

Opracowane zostały zasady i organizacja deponowania prac w SOPD. Trwają prace nad automatyzacją przenoszenia prac dyplomowych z wyżej wymienionego systemu do Repozytorium AGH.

W okresie przejściowym, czyli do 31 grudnia 2016 r., prace będą realizowane dwutorowo. Na poszczególnych wydziałach pracować będą tak zwane Lotne Brygady, które zajmą się opracowaniem zasobu za okres październik 2009 r. - maj 2015 r. Przeszkolone i posiadające stosowne certyfikaty na dostęp do teczek osobowych studentów i na przetwarzanie danych osobowych zespoły rozpoczęły prace pod koniec lutego $2015 \mathrm{r}$. Ich zadaniem jest weryfikacja i/lub uzupełnianie metadanych, pobranych z systemu dziekanat.xp, bądź wprowadzanie wymaganych przez ustawę metadanych ${ }^{8}$, gdy brak ich będzie w omawianym systemie oraz wczytywanie do Repozytorium AGH plików $\mathrm{z}$ tekstami prac. Testy przeprowadzone wcześniej na próbce prac dyplomowych jednego z wydziałów nie wypadły optymistycznie, bowiem wiele plików było uszkodzonych, co spowodowało, że nie było można ich odczytać oraz przekopiować do Repozytorium. Decyzją władz rektorskich, w przypadku stwierdzenia uszkodzeń plików, mają być sporządzane odpowiednie protokoły. Jak dotąd, mimo zapowiedzi, Ministerstwo nie przygotowało wzoru takiego protokołu.

Kolejny problem, z którym będą musiały się zmierzyć uczelnie, głównie techniczne, wiąże się z koniecznością dokonywania identyfikacji typu pracy, czyli rozróżniania, czy praca jest pracą pisemną czy projektem inżynierskim. W myśl ustawy, w ORPD mają być rejestrowane „pisemne prace dyplomowe", , co ma swoje uzasadnienie; zawartość ORPD będzie służyć jako materiał porównawczy dla systemu antyplagiatowego. Jak jednak na poziomie uczelni odróżnić prace pisemne od projektów inżynierskich? Przy próbach identyfikacji nie można kierować się jedynie tytułem, bowiem nie zawsze z niego wynika, czy jest to typowy projekt inżynierski czy praca zawierająca tekst. Tak

\footnotetext{
${ }^{8}$ Tytuł pracy dyplomowej, imiona i nazwisko autora pracy dyplomowej, imiona i nazwisko promotora pracy dyplomowej, imiona i nazwiska recenzentów pracy dyplomowej, nazwa podstawowej jednostki organizacyjnej, nazwa uczelni, datę zdania egzaminu dyplomowego, nazwa kierunku studiów.

${ }^{9}$ Ustawa z dnia 11 lipca 2014 r. o zmianie ustawy Prawo o szkolnictwie wyższym oraz niektórych innych ustaw, „Dziennik Ustaw” 2014, poz. 1198, art. 167 a, 167 b.
} 
więc dopiero wgląd $w$ daną pracę pozwoli na wiarygodną identyfikację jej typu. Być może nie będzie to praca trudna, ale z pewnością czasochłonna, co przy okresie danym na wykonanie całości prac ma niebagatelne znaczenie.

Na podstawie danych zebranych z wydziałów wynika, że Lotne Brygady będą miały do wprowadzenia do Repozytorium ponad 35 tys. prac archiwalnych.

Innym trybem objęte zostaną prace bieżące. Rocznie w AGH bronionych jest około 7 tys. prac. Najbliższe obrony przewidziane są na okres od czerwca do października 2015 r. Prace te będą deponowane przez studentów w systemie SOPD, następnie oceniane przez opiekunów (promotorów), opiniowane przez recenzentów, sprawdzane przez opiekuna systemem antyplagiatowym. Po pozytywnym przejściu wszystkich kroków student będzie mógł wydrukować pracę osygnowaną specjalnym kodem. Po obronie praca wraz z niezbędnymi metadanymi będzie pobierana do bazy zasadniczej czyli Repozytorium AGH, a następnie przekazywana do POL-onu (do ORPD). Początkowo zakładano, że do obsługi prac dyplomowych wykorzystany zostanie system dziekanat.xp. W praktyce rozwiązanie to okazało się niemożliwe. Należało zatem opracować nową koncepcję. Ostatecznie zdecydowano, że także do obsługi prac dyplomowych wykorzystane zostaną możliwości oprogramowania DSpace, a narzędzie opracują pracownicy Biblioteki Głównej AGH we współpracy z informatykami Uczelnianego Centrum Informatyki. Prace nad tym systemem trwają, a pilotażowy produkt zostanie poddany próbie podczas rejestrowania prac licencjackich (czerwiec - lipiec) oraz magisterskich (czerwiec - październik).

\section{Inne prace}

Równolegle w ramach projektu Repozytorium AGH realizowany jest podprojekt „Historia AGH”. Wykorzystano w nim zasoby lokalnych baz, od wielu lat tworzonych przez Bibliotekę Główną: BIOGRAM i DHC. Baza BIOGRAM (wcześniej w formie tradycyjnej kartoteki) początkowo obejmowała wszystkie znaczące postaci Uczelni. Później zaczęto do niej wprowadzać także notki o osobach, o których pojawiały się wzmianki w innych źródłach. Kilka lat później zaczęto tworzyć bazę rejestrującą doktorów honorowych AGH. Po zmianie oprogramowania (przejście z ISIS-a na wiki), scaleniu baz, dodaniu portretów, uzupełnieniu o źródła, stały się one podstawą serwisu „Historia AGH”10.

\section{Wspólpraca}

Inicjatorem budowy repozytorium instytucjonalnego w AGH była Biblioteka Główna. Po przedstawieniu założeń do projektu władze rektorskie przychyliły się do propozycji budowy Repozytorium AGH i zaleciły opracowanie szczegółowego projektu oraz harmonogramu prac. Z uwagi na to, że projekt

\footnotetext{
${ }^{10}$ Historia AGH, [dostęp: 25.02.2015], http://historia.agh.edu.pl/wiki/Strona_główna.
} 
Repozytorium obejmuje wiele obszarów działalności Uczelni, niezbędne było nawiązanie współpracy w tym zakresie z Uczelnianym Centrum Informatyki, Działem Nauczania, dziekanatami na poszczególnych wydziałach, Muzeum $\mathrm{AGH}^{11}$. W przyszłości planowane jest podjęcie współpracy w zakresie Repozytorium także z innymi jednostkami Uczelni, między innymi: Archiwum AGH, Wydawnictwami AGH, Centrum e-Learningu. Z częścią tych jednostek Biblioteka Główna od wielu lat współpracuje w innych obszarach i są tego wymierne efekty (współpraca z UCI w zakresie implementacji nowych rozwiązań technicznych, informatycznych w odniesieniu do Bibliografii Publikacji Pracowników AGH, współpraca z Wydawnictwami AGH w zakresie pozyskiwania elektronicznych wersji publikacji dla biblioteki cyfrowej i temu podobne).

Jest to zatem przedsięwzięcie długoterminowe, wielozadaniowe, obejmujące wiele aspektów działalności Uczelni, wymagające udziału wielu jednostek. Wkrótce wejdą $\mathrm{w}$ życie wewnętrzne akty prawne, które określą kompetencje i zadania poszczególnych jednostek oraz zadania i tryb pracy w Repozytorium AGH.

\section{Regulacje prawne}

Przyjęto założenie, że w formie zarządzeń rektora AGH ukażą się dwa regulaminy: regulamin w sprawie gromadzenia, przechowywania i udostępniania cyfrowych zasobów instytucjonalnych w bazie wiedzy pod nazwą Repozytorium AGH oraz regulamin opisujący tryb i zasady deponowania i obiegu prac dyplomowych w SOPD. Projekt pierwszego z nich opracowany został przez Bibliotekę Główną, opracowanie drugiego leży w kompetencjach Działu Nauczania AGH. Oddzielnie przygotowana zostanie szczegółowa instrukcja umieszczania danych w Repozytorium AGH.

\section{Organizacja i zarządzanie projektem}

Prace projektowe nad Repozytorium AGH rozpoczęto od opracowania schematu organizacyjnego, w którym poszczególnym osobom czy grupom osób przypisano podstawowe zadania i określono ich kompetencje. Powołano Komitet Sterujący, na czele którego stanął prorektor ds. nauki. Kierownikiem projektu została dyrektor BG, a jej zastępcą - dyrektor UCI. Ponadto powołano trzy stałe zespoły: merytoryczny, techniczny i ekonomiczny. W trakcie realizacji projektu, w miarę potrzeb, powoływane są także zespoły robocze dla rozpracowania lub wykonania konkretnego zadania. I tak między innymi powstał zespół Lotnych Brygad, którego zadaniem jest wprowadzenie do Repozytorium AGH metadanych i plików zawierających prace dyplomowe

\footnotetext{
${ }^{11}$ Muzeum AGH w zakresie merytorycznego wsparcia podprojektu „Historia AGH”.
} 
(za okres: październik 2009 r. - maj 2015 r.). Zespół składa się z kilku dwuosobowych podzespołów, które przede wszystkim będą pracować na wydziałach. Równolegle pracuje Zespół do spraw Historii AGH, pod kierunkiem zastępcy dyrektora Biblioteki Głównej. Zadaniem kolejnego zespołu jest przygotowanie narzędzia do SOPD. Opracowany został ramowy harmonogram całego projektu oraz szczegółowy - na 2014 r. Podobny przygotowany został na $2015 \mathrm{r}$. Na bazie harmonogramu powstał kosztorys, w którym ujęto koszty zakupu sprzętu komputerowego oraz wynagrodzeń za dodatkowe prace, wykonywane poza obowiązkami służbowymi.

\section{Podsumowanie}

Co pewien czas nad bibliotekami, jak miecz Damoklesa, zawisa widmo końca ich istnienia. Tu i ówdzie słyszy się, że w dobie komputeryzacji, informatyzacji, gdy już wszystko jest w Internecie, biblioteki nie są potrzebne. I faktycznie, na tej fali polikwidowano wiele bibliotek publicznych, a w akademickich ogranicza się zatrudnienie. Wydaje się jednak, że biblioteki powinny wykorzystywać wszelkie okazje, by nadal funkcjonować, przyjmując jako warunek podstawowy i bezwzględny to, że konieczne jest permanentne przekształcanie się i dostosowywanie do zmieniających się uwarunkowań i otoczenia.

Jak napisano we wstępie, wiele bibliotek podjęło się budowy repozytoriów instytucjonalnych, zanim wynikło to z nakazów ministerialnych. Podobnie wcześniej było z rejestracją dorobku publikacyjnego pracowników. Dzisiaj w wielu uczelniach nikt nie wyobraża sobie oceny pracowników czy parametryzacji wydziałów bez wsparcia biblioteki uczelnianej. Coraz częściej w zarządzeniach rektorskich spotykamy się ze sformułowaniami i stwierdzeniami, że jedyne wiarygodne źródło danych o dorobku publikacyjnym to bibliograficzna baza biblioteczna, że biblioteka wyliczy, biblioteka przygotuje i temu podobne. A więc jednak w wielu uczelniach bez biblioteki funkcjonować się nie da.

W lipcu ubiegłego roku ustawa wprowadziła obowiązek rejestrowania i przesyłania do POL-onu prac dyplomowych. Nikt nie wskazywał, że mają się tym zająć biblioteki akademickie. Ale mogły skorzystać z szansy, zaproponować swoje usługi, kompetencje, doświadczenie i włączyć się do prac.

Ostatnio podjęta przez BG AGH inicjatywa jest jednym z większych przedsięwzięć ostatnich kilku lat. Projektem docelowo objęta będzie cała uczelnia z jej bieżącą działalnością, jak i wszystko, co ważne, z przeszłości. Podstawowym warunkiem powodzenia przedsięwzięcia jest kompetentny, zaangażowany zespół pracowników: bibliotekarzy i informatyków, dobrze układająca się współpraca z poszczególnymi jednostkami Uczelni, przychylność władz oraz przejrzyste i sprawne zarządzanie zasobami ludzkimi i całym projektem. 


\section{Bibliografia}

Historia AGH, [dostęp: 25.02.2015], http://historia.agh.edu.pl/wiki/Strona_główna.

Karwasińska E., Rychlik M., Model i etapy tworzenia repozytorium instytucjonalnego na podstawie badań własnych $i$ doświadczeń bibliotek zagranicznych, „Informacja dla Nauki a Świat Zasobów Cyfrowych" 2008, s. 10-20, [dostęp: 23.02.2015], http://library.put. poznan.pl/konf_idn/art/1_2.pdf.

Kulczycki E., Repozytorium jest ważne dla naukowców i uczelni. AMUR jako wzór, [dostęp: 23.02.2015], http://ekulczycki.pl/warsztat_badacza/repozytorium-jest-wazne-dla-naukow cow-i-uczelni-amur-jako-wzor/.

Lynch C.A., Institutional Repositories: Essential Infrastructure for Scholarship in the Digital Age, “ARL: A Bimonthly Report", No. 226 (2003), [dostęp: 19.02.2015], http://www.arl. org/resources/pubs/br/br226/br226ir.shtm.

Mikołajuk L., Repozytorium instytucjonalne jako nowa forma komunikacji naukowej, „Podkarpackie Studia Biblioteczne" 2014, nr 3, [dostęp: 23.02.2015], http://dspace.uni. lodz.pl:8080/xmlui/bitstream/handle/11089/5071/repozytorium_instytucjonalne_1.pdf?seq uence $=1 \&$ isAllowed $=\mathrm{y}$.

Mitkowski S., Elektrotechnika ogólna: ćwiczenia laboratoryjne, Kraków 1999, [dostęp: 19.02.2015], http:// winntbg.bg.agh.edu.pl/skrypty/0002/.

Repozytorium Uniwersytetu Warszawskiego - promuje $i$ zwiększa cytowania, [dostęp: 24.02.2015], http://www.buw.uw.edu.pl/index.php?option=com_content\&task=view\&id= $1561 \&$ Itemid $=241$.

Ustawa z dnia 11 lipca 2014 r. o zmianie ustawy Prawo o szkolnictwie wyższym oraz niektórych innych ustaw, „Dziennik Ustaw” 2014, poz. 1198, art. 167 a, 167 b.

Wikipedia, the free encyclopedia, [dostęp: 19.02.2015], http://en.wikipedia.org/wiki/Institu tional_repository. 